\title{
The Influence OF Technological InNOvation ON TOURISM Enterprises' Performance: A Comparative Study of Travel Agents ANd Hotels in EgYPT
}

\author{
Mohammad Soliman \\ Tourism Studies Department \\ Faculty of Tourism and Hotels, Fayoum University \\ Mohammed Sheded \\ Tourism Studies Department \\ Faculty of Tourism and Hotels, Fayoum University
}

\begin{abstract}
Given the rapid development of competition, organizations are in urgent need for creating viable new concepts, activities, and practices. In recent years, innovation has emerged as a pressing theme for most organizations involved in service industry. Technological innovation competencies are being required in all fields and at all levels in tourism and hospitality industry. This study aims to examine the influence of technological innovation on tourism and hospitality enterprises' performance in Egypt. Quantitative approach is used to achieve the aim of the study. Questionnaires were distributed and collected from managers in travel agencies category 'A' and five star hotels in Egypt. The main findings of the study are: product and process innovations have a significant effect on production, financial, and market performance of Egyptian travel agents and hotels. This study is useful for tourism and hospitality organizations that are in imperative need to improve their performance. This study is contributing to knowledge by providing insights from tourism and hotel sector in a developing country, Egypt.
\end{abstract}

Keywords: innovation, technological innovation, travel agents, hotels, Egypt

\section{Introduction}

In today's competitive economic conditions, which call for innovation, one cannot consider only the idea that innovative process come exclusively from gifted people, or that innovation is an intellectual accident of inspiration and not the result of hard and focused work (Drucker, 2002). Innovation is not only the act of introducing something new, but also becoming widely adopted. Thus, innovation defined as the process of converting opportunities into new ideas and using them into various practices (Lin \& Ho, 2008).

The ability of any organization to innovate is a prior process for the successful utilization of inventive resources and new technologies. Conversely, the implementation of new technology often presents a complex opportunities and challenges for organizations, leading to changes in production practices and the emergence of new organizational forms. Hence many types of innovation are developed and promoted (Lam, 2004). However, the analysis of innovation has long been definite to technological innovation and few studies have been dedicated to other forms of innovation (Hamidi \& 
Benabdeljlil, 2015). In essence, technological innovation is the way in which an organization can efficiently select, implement and use a technology in comparison with a competitor (Azubuike, 2014).

The critical role of innovation is supposed to be a basic factor in creating value and enhancing organizations performance (Hamidi \& Benabdeljlil, 2015). Innovation is becoming an important feature in creating competitiveness in operations and services (Castellacci, 2008; Möller, Rajala, \& Westerlund, 2008). Ithelps organizations in surviving unfavorable global financial conditions (Rampersad, Plewa, \& Troshani, 2012). Cabral (2011) confirmed that the fields of innovation and sustainability are more and more recognized as the major aspects of business in the 21 st century. Despite firms need a continuous innovation process to comply with the fast environmental changes, the goal of sustainability requires new ways of doing business. In addition, governments in many countries have identified innovation as a core element of their progressive policies (Rampersad, et al., 2012; Tsai, Lin, \& Kurekova, 2009).

Tourism and hospitality is a huge industry with continuous changes in trends, perspectives and customer's needs, which makes innovation a vital issue to stand out from the severe competition with successful applications and practices (Sipe \& Testa, 2009). Innovation in tourism and hospitality industry includes all aspects of formation and development of creative devices or improvement of better tourism and hospitality services leading to higher customer's satisfaction, more effective managerial strategies, increasing profits, and decreasing costs as end results (Pirnar, Bulut, \& Eris, 2012).

Although the concept of innovation is vital for today's competitive tourism and hospitality industry for long-term success, innovation in this industry is featured by limited and insufficient researches and studies (Meneses \& Teixeira, 2011; Orfila-Sintes \& Mattsson, 2009; Weiermair, 2006). In addition, there is a limited theoretical work related to developing the relationships between information technology (IT) and service innovation processes (Chen \& Tsou, 2007). IT is the backbone of any innovation processes, which play a great role in enhancing the performance of tourism sector. However, there is insufficiency of studies dealt with the influence of technological innovations and performance in tourism and hospitality enterprises; as a result, the development of these establishments depending on the integration between IT channels and innovation processes is still at its infancy stage (Adeyeye, Jegede, \& Akinwale, 2013).

Based on what was mentioned above, this paper aims to investigate the impact of technological innovation including product innovation and process innovation, on production, financial, and market performance of Egyptian travel agents category 'A' and five star hotels.

\section{Literature Review}

Innovation Overview: Innovation is the process of making changes, large and small, fundamental and gradual, to products, processes, and services. This result in the introduction of something new for the organization that adds value to customers and takes part in establishment knowledge storage (Susman, Warren, Ding, \& Stites, 2006).

Fortuin et, al. (2007) defined innovation as a process of creative destruction, where the pursue for profits pushes to innovate constantly, by breaking traditional rules to establish new ones. This adopts not only the introduction of new products but also the successful 
commercialization of new integrations, based on the application of new ideas, devices, materials and components, the introduction of new processes, the opening of new markets or the introduction of new establishment forms.

Innovationis also defined as the implementation of a product (good or service), or a new or significantly modified process, a new marketing strategy, or a new organizational method in business practices, workplace establishment or external working relationships (Hamidi \& Benabdeljlil, 2015). Moreover, innovation provides the possibilities to achieve the objectives of enterprises and the community as a whole(Macerinskiene \& Mikaliuniene, 2014).

Hence, innovation is not a single action but a total process of interrelated sub processes. It is not just the conception of a new idea, nor the invention of a new device, not the development of a new market. The process is all of these things acting in an integrated trend. Therefore, the innovation process involves activities and decisions from idea generation to the final launch of the product onto the market (Fortuin, et al., 2007).It is obvious also that although much of the discussion of innovation focuses on new products and technologies, all innovation techniques are based on challenging existing suppositions and ways of thinking (Moscardo, 2008).

Taking the different definitions of innovation into consideration, it may be concluded that; innovation in tourism and hospitality industry may be attained by means of new services, new target groups and consumers, new channels of distribution, new promotion tools and strategies, new marketing applications or new infrastructures (Peters \& Pikkemaat, 2006).

Innovation is a diverse activity. And it can be distinguished between different sorts of innovation according to nature and degree of innovation. Indeed, the first distinction regarding the nature of innovation, occurs in the activity of the enterprise, depending on whether it relates to products, processes, the organization and/ or marketing. The second type is the innovation degree. It can distinguish between radical innovation and incremental innovation, and thus the type of change in the business and their impact on the market and/or technology(Hamidi \& Benabdeljlil, 2015).

In addition, there are different forms of innovation, which usually come in the style of: manufacturing innovations, process innovations, management innovations, logistics innovations, and institutional innovation (Ivanovic, Katic, \& Mikinac, 2010; Pirnar, et al., 2012). Finally, innovation can be classified as: technological innovation (i.e. product innovation and process innovation) and non-technological innovation (i.e. organizational and marketing innovations) (Gunday, Ulusoy, Kilic, \& Alpkan, 2011; OECD, 2005; Polder, Leeuwen, Mohnen, \& Raymond, 2010; Schmidt \& Rammer, 2007).

This diversity makes it difficult for a precise definition of innovation and makes incomplete, often, the distinction between types (Hamidi \& Benabdeljlil, 2015).

Technological Innovation: Organizations recently interact with an environment characterized by increasing competition and the rapid evolution of technological challenges. These challenges need integration between IT, organizational structures, processes, and practices to adopt new products and services, and to achieve competitive advantages (Agbim, 2013; Teece, 2007). Technological innovation, here, is broadly seen as an essential component of competitiveness, embedded in the organizational structures, processes, products, and services within an institution(Azubuike, 2014).

According to Yam, et al., (2004) technological innovation is the combination of knowledge techniques and management skills from different areas, that by strengthening 
these areas, the company can build its organizational competitiveness. Technological innovation is the ability to access and digest external knowledge into some unique skill or knowledge, then using it in a dynamic way to improve or develop a new product and launch it successfully (Archibugi \& Coco, 2005). Beside, technological innovation involves using technology in new ways to create a more efficient organization and improve harmony between technology initiatives and its goals and aims (Rouse, 2011).

Letangule \& Letting (2012) stated that technological innovation is considered as a process which is science, technology and system based. This process includes several characteristics affecting and affected by the establishment's internal qualifications, its networking and technological learning ability are influenced by its environmental factors. It would gather all existing potential resources to increase the firm's innovation capacities, ending with the introduction of a new or better product and production process.

Innovation applications fall within the group of IT involving networked systems that focus on knowledge management and collaboration (Cooper, 2003). To be recognized as an innovation, a technology application must not only be new or creative, but should have: demonstrated market need; newness; technical soundness; processes for managing the risks involved in development; and user friendliness (Carson \& Richards, 2004).

The literature clearly shows that some technologies systems are better structured to adopt and employ innovation than others (Carson \& Richards, 2004). A number of information systems researchers such as (Corso \& Paolucci, 2001; Dewett \& Jones, 2001; $\mathrm{Xu}$, Sharma, \& Hackney, 2005) have assumed that IT is an important ingredient of innovation development. As many innovation activities involve adding new services, expanding existing ones and/or improving the service delivery process, the success of an organization depends on how well it implements its innovation to create new markets (Berry, Shankar, Parish, Cadwallader, \& Dotzel, 2006).

Technological innovation can take many forms. For instance, it can be used to turn business processes into automated IT functions and to develop applications that open new markets. Many establishments try to originate the process of innovation by creating innovation teams from diverse segments of the enterprise. Other firms rely on individual employees to enhance an environment where technological innovation is required (Rouse, 2011).

Types of Technological Innovation: According to some resources (Gunday, et al., 2011; OECD, 2005; Polder, et al., 2010; Schmidt \& Rammer, 2007)it is obvious that technological innovation divided into two main types; technological product innovation, and technological process innovation.

a. Product innovation: Product innovation means the implementation of a product with improves performance features such as to deliver objectively new or improved services to the customer (OECD, 2005). Product innovation is introducing the new products/services or brining significant development in the existing products/services (Polder, et al., 2010). This includes significant modifications in technical aspects, components, and materials, incorporated software, user friendliness or other functional characteristics. Product innovations can use new knowledge or technologies, or can be rely on new integrations of existing knowledge or technologies (Corsino \& Gabriele, 2010).

Product innovation has many dimensions. First, from the perspective of the customer, product is new to the customers. Second, from the perspective of the establishment, the product is new to the establishment. Third, product improvement means bringing product 
variation in the existing products of the organizations (Masood, Shaukat, Nawaz, \& Naz, 2013).

The aim of product innovation is to attract new customers and try to reach high degrees of their satisfaction by introducing new products or improve the existing products according to needs of the customers (Adner \& Levinthal, 2001). Product innovation is an important strategy for increasing the market share and developing enterprise performance. It has positive impact on the performance of the enterprises (Masood, et al., 2013; Roberts, 1999). Then we can say that product innovation is one of the key elements that lead to tourism organization success.

b. Process innovation: Process innovation is defined as the implementation of the production or delivery method that is new or significantly improved. It includes bringing significant improvement in the equipment, technology, and software of the production or delivery method(OECD, 2005).In addition, process innovation is the introduction of a new method of production that had never been used before, and a new way of handling a commodity commercially to make production more efficient or to be able to produce new or improved products (Corsino \& Gabriele, 2010). This includes improvements in the supporting activities such as purchasing, accounting, maintenance and computing, customer service (information inquiry and consultation), providing after-sales services, and internal administration and operations (Davenport, 2013; Polder, et al., 2010).

Process innovation is important to produce innovative products and adjusted processes within establishments and to produce the new products. It can be intended to decrease unit costs of production or delivery, to increase quality, or to produce or deliver new or significantly improved products (Adner \& Levinthal, 2001).

In tourism enterprises, process innovations include new or significantly improved ways for the creation and provision of services. They can involve significant changes in the equipment and software used in services-oriented enterprises or in the procedures or techniques that are employed to deliver services. Examples are the introduction of GPS tracking devices for transport services, the implementation of a new reservation system in a travel agency, and the development of new techniques for managing projects in tourism organizations (OECD, 2005).

The Influence of Technological Innovation on Tourism Enterprises' Performance Regarding the environmental conditions, establishments seek to develop and improve their administrative aims and methods by changing its organizational structure in line with technology adoption in innovative way. Thus, technological innovation becomes an important concept for growth, business improvement, and different advantages in organization performance(Benner \& Tushman, 2002).Technological innovation is related to creative concepts on; easier problem solving, value-adding operations and methods and application of more efficient or unique ways while producing and delivering products and sevices (Pirnar, et al., 2012).

The use of technological innovation in many organzations, including tourism and hospitalityenterprises, intends to increase the competitiveness through the increase of the productivity and improving quality service and/or introducing new products (Meneses \& Teixeira, 2011). According to some resources(Masood, et al., 2013;Azubuike, 2014), product innovation and process innovation, which categorized as technological innovation, have impact on production performance in organizations by providing new products and services to the market comparing to competitors, introducing innovative 
processes and methods, improving quality of new products and services introduced, increasing production volume, enhancing production flexibility, speed delivery of products, and conformance quality. Innovative establishments are discovered to be more productive than non-innovative enterprises.

The relationship between adopting technological innovation and improving performance is based on the supposition that the majority of theses organizations are not able to compete with lower cost and prices through a cost leadership strategy, but can survive using a different strategy through innovation. That is not to deny that most technological innovations in the tourism and hospitality establishments may be oriented and aimed to decrease their costs through innovation that passed on developed quality of products or services (Perez, 2012).

Cainelli et, al. (2006) mentioned that technological innovation have a positive impact on the economic performance of services organizations including tourism and hospitality enterprises. Moreover, the two types of technological innovations have positively affected on financial performance of enterprises which includes some measures such as; reducing production cost, increasing return on investment, increasing return on assets, improving return on sales, and increasing profitability (Gopalakrishnan, 2000; Masood, et al., 2013; Azubuike, 2014).

Theimpact of technological innovation on tourism and hospitality enterprises is positively associated with turnover and employment growth(Haiyu \& Qian, 2014). Moreover, technological innovation is an important source of growth and a key determination of competitive advantage for many organizations (Azubuike, 2014). Additionally, technological innovation has positive impacts of the on market performance especially on customer satisfaction, market share, total sales (Al-Zyadaat, Saudi, \& AlAwamreh, 2012; Azubuike, 2014; Masood, et al., 2013), competitive advantage (Chen \& Tsou, 2007), and customer loyalty (Naveed, et al., 2012).

In this context, tourism and hospitality establishments need to realize that technological innovation can be used not only for operational purposes, but also for tactical and strategic management. This can help to empower these establishments to communicate directly and more efficiently with prospective customers and suppliers as well as to achieve economies of scale (Ashari, Heidari, \& Parvaresh, 2014).

From the above studies, technological innovation could be seen as a multi-dimensional concept, which tackles the diffusion and application of technology in order to acquire production, financial, and market benefits (Azubuike, 2014).

\section{Proposed Research Model and Hypotheses Development}

Building upon the literature review, the proposed research model of this paper conceptualizes the causal relationships among technological innovation and performance dimensions. Technological innovation is measured in two dimensions: product and process innovations (independent variables). Performance dimensions (dependent variables) are measured by three constructs; production, financial, and market performance (Figure 1). 


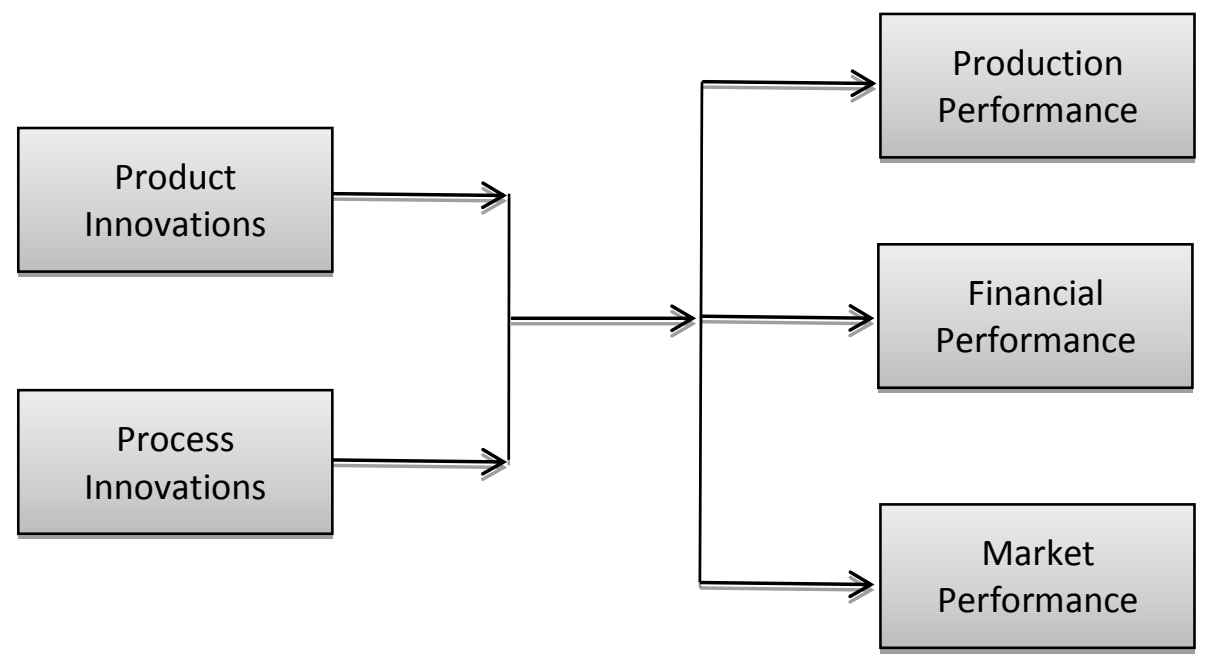

Figure 1.Proposed research model and hypotheses

From the proposed model, the following hypotheses were developed:

H1. Technological innovation has a significant influence on production performance of Egyptian travel agents and hotels

H1a. Product innovation has a significant influence on production performance of Egyptian travel agents and hotels.

H1b. Process innovation has a significant influence on production performance of Egyptian travel agents and hotels.

$\mathrm{H} 2$. Technological innovation has a significant influence on financial performance of Egyptian travel agents and hotels.

$\mathrm{H} 2 \mathrm{a}$. Product innovation has a significant influence on financial performance of Egyptian travel agents and hotels.

$\mathrm{H} 2 \mathrm{~b}$. Process innovation has a significant influence on financial performance of Egyptian travel agents and hotels.

H3. Technological innovation has a significant influence on market performance of Egyptian travel agents and hotels.

H3a. Product innovation has a significant influence on market performance of Egyptian travel agents and hotels.

$\mathrm{H} 3 \mathrm{~b}$. Process innovation has a significant influence on market performance of Egyptian travel agents and hotels.

\section{Research Methodology}

Drawing on the aforementioned discussion, online questionnaire is used to collect data from managers of travel agents category 'A' and five star hotels in Egypt. The questionnaire is developed based on literature review. The final form has 24 five-point Likert scale statements, ranging from 1 (strongly disagree) to 5 (strongly agree). The form includes 8 statements to measure technological innovation (Table 1).

Technological innovation's measurement is divided into two main categories; product innovation (4 statements: product innovation help: improving existing products/services, repackaging existing products/services, creating new lines of products/services, and developing new products and services) (Masood, et al., 2013; OECD, 2005; Polder, et al., 2010). In addition, process innovation (4 statements: customer service, promoting and 
selling products, after-sales services, and internal administration and operations) (Corsino \& Gabriele, 2010; Polder, et al., 2010; Davenport, 2013).

Additionally, 16 statements to measure performance dimensions. Performance dimensions' measurement is divided into three main categories. Firstly, production performance ( 7 statements: new products and services to the market comparing to competitors, innovative processes and methods, quality of new products and services introduced, production volume, production flexibility, speed delivery of products, conformance quality) (Masood, et al., 2013; Azubuike, 2014). Secondly, financial performance (4 statements: production cost, return on investment, return on sales, and profitability) (Gopalakrishnan, 2000; Masood, et al., 2013; Azubuike, 2014). Finally, market performance (5 statements: customer satisfaction, market share, total sales (Masood, et al., 2013; Azubuike, 2014), competitive advantage (Chen \& Tsou, 2007), and customer loyalty (Naveed, Akhtar, \& Cheema, 2012). The questionnaire was piloted on 30 travel agents and 20 five star hotels and statistics showed an evident construct validity and reliable measurement.

The population of the study encompasses travel agents Category 'A'and five star hotels in Egypt. Category 'A' travel agents are licensed to work in inbound and outbound tourism activities and its related services (Hassan \& Soliman, 2013). A five star hotel is an establishment where guests can find spacious and luxurious accommodation that matches the best international standards. Staff will be knowledgeable, helpful, well versed in all aspects of customer care, combining efficiency with courtesy (Narangajavana, 2007).

Travel agents category 'A' were selected due to diversified activities, and the availability of human and financial resources (Hassan \& Soliman, 2013). The choice of five-star hotels was due to the following considerations: leadership in the hospitality industry, using the modern technological and production concepts, and the enthusiasm towards the continuous improvement of their performance through utilizing innovation practices (Gad-ElRab, 2010; Minazzi, 2010).

Regarding the sample, there is a total of 1230 travel agents category'A' in Egypt (Egyptian Travel Agents Association, 2014). In addition, there are 158 five star hotels in Egypt (Hotels Supervision Sector, 2013). The ideal sample size best represents the population of the study (Sekaran, 2006) is 292 forms for travel agents, and 122 forms for five star hotels. These forms were completed online by travel agents' and five star hotels' managers and were found free of missing data and valid for analysis purposes. Data collection was carried out during the period of March-July 2015. Deductive quantitative approach was used to test the hypotheses of the study.

\section{Findings of the Study}

Validity and Reliability: To validate the five main constructs of the study; product innovation, process innovation, production performance, financial performance, and market performance, corrected item-total correlations were calculated. The values of these correlations, table (1), range between 0.35 and 0.85 implying valid constructs of the measurement (Netemeyer, Bearden, \& Sharma, 2003).

The reliability for the main constructs of the study revealed Chronbach's alpha values of 0.794 for product innovation for travel agents and 0.907 for hotels. For process innovation (the value is 0.828 for travel agents and 0.881 for hotels), for production performance ( 0.885 for travel agents and 0.934 for hotels), for financial performance 
(0.842 for travel agents and 0.913 for hotels), and for market performance ( 0.873 for travel agents and 0.941 for hotels). Since the results are significantly higher than the value of 0.7, the questionnaire is deemed to have excellent stability and consistency (Hair, Black, Babin, Anderson, \& Tatham, 2006; Streiner, 2003; Vogt, 2007).

Table 1: Results of the validity and reliability tests

\begin{tabular}{|c|c|c|c|c|}
\hline & \multicolumn{2}{|c|}{ Travel agents } & \multicolumn{2}{|c|}{ Five star hotels } \\
\hline & $\begin{array}{c}\text { Corrected Item- } \\
\text { Total } \\
\text { Correlation } \\
\end{array}$ & $\begin{array}{l}\text { Alpha } \\
\text { Value }\end{array}$ & $\begin{array}{c}\text { Corrected Item- } \\
\text { Total } \\
\text { Correlation } \\
\end{array}$ & $\begin{array}{l}\text { Alpha } \\
\text { Value }\end{array}$ \\
\hline Product Innovation & & \multirow{5}{*}{.794} & & \multirow{5}{*}{0.907} \\
\hline Improving existing products/services & $.7 \leqslant 9$ & &.$\wedge \cdot \varepsilon$ & \\
\hline Repackaging existing products/services & .597 & & .10 & \\
\hline Creating new lines of products/services & .548 & &.$\wedge r V$ & \\
\hline Developing new products and services & .648 & & Art & \\
\hline Process Innovation & & \multirow{6}{*}{.828} & & \multirow{6}{*}{.881} \\
\hline Customer service (information inquiry and & .701 & &.$v \cdot 9$ & \\
\hline consultation) & & &.$\wedge r \mu$ & \\
\hline Promoting and selling products/services & r & & $. v \leq r$ & \\
\hline Providing after-sales services & $.7 \cdot 4$ & &.$v \cdot \Lambda$ & \\
\hline Internal administration and operations & $.7 \wedge \varepsilon$ & & & \\
\hline Production Performance & & \multirow{8}{*}{.885} & & \multirow{8}{*}{.934} \\
\hline $\begin{array}{l}\text { New products and services to the market } \\
\text { comparing to competitors }\end{array}$ & r & &.$A r r$ & \\
\hline Innovative processes and methods & Vor & &.$\wedge 1$. & \\
\hline $\begin{array}{l}\text { High quality of new products and services } \\
\text { introduced }\end{array}$ &.$v r v$ & &.$\wedge 11$ & \\
\hline Increased production volume, and & .7 .0 & &.$\wedge \varepsilon$ & \\
\hline Production flexibility & .704 & & .700 & \\
\hline Speed delivery of products &.$\leqslant 09$ & & Aro & \\
\hline Conformance quality & .200 & &.$V \cdot r$ & \\
\hline Financial performance & & \multirow{5}{*}{.842} & & \multirow{5}{*}{.913} \\
\hline Reduced production cost & $.77 r$ & &.$\vee \vee \wedge$ & \\
\hline High return on investment & $.7 \vee 7$ & &.$\wedge 11$ & \\
\hline High return on sales & .700 & & . var & \\
\hline Increased profitability &.$V Y \varepsilon$ & &.$\vee \vee \varepsilon$ & \\
\hline Market performance & & \multirow{6}{*}{.873} & & \multirow{6}{*}{.941} \\
\hline Focused on customer satisfaction &.$\vee 7$. & &.$\wedge \cdot 1$ & \\
\hline Increased total sales &.$v \cdot 7$ & &.$\wedge 2 r$ & \\
\hline Increased customer loyalty & $. v \leqslant r$ & & $. \wedge \leqslant \vee$ & \\
\hline Extended market share & 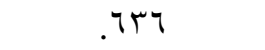 & &.$\wedge 2 \varepsilon$ & \\
\hline Improved competitive advantage & .701 & &.$\vee 9$. & \\
\hline
\end{tabular}

Descriptive Analysis: Table (2) depicts the mean values and standard deviations of the research model. It is revealed that managers of travel agents and hotels agree to the types of technological innovation (product innovation and process innovation), and this leads to a conclusion that Egyptian travel agents and hotels adopt activities and practices of technological innovation. These activities include product innovation such as; improving 
existing products/services, repackaging existing products/services, creating new lines of products/services, and developing new products and services. Additionally, process innovation includes; customer service, promoting and selling products/services, providing after-sales services, and internal administration and operations.

Moreover, managers of travel agents and hotels agree thatproduct innovation and process innovationcould positively affect the enterprise performance: production, financial, and market-related. These findings reflect the influence of technological innovation on performance dimensions in Egyptian travel agents and hotels.

Table 2: Descriptive analysis of research model constructs

\begin{tabular}{|l|c|c|c|c|}
\hline & \multicolumn{2}{|c|}{ Travel agents } & \multicolumn{2}{c|}{ Five star hotels } \\
\hline & Mean & S. deviation & Mean & S. deviation \\
\hline Product Innovation & 3.93 & 0.68 & 3.76 & 0.98 \\
\hline Process Innovation & 3.91 & 0.73 & 3.88 & 0.93 \\
\hline Production Performance & 3.90 & 1.19 & 3.78 & 1.73 \\
\hline Financial performance & 3.97 & 0.68 & 3.91 & 0.92 \\
\hline Market performance & 4.03 & 0.89 & 3.83 & 1.20 \\
\hline
\end{tabular}

Regression Analysis. A regression analysis was used to investigate the influence of the two main dimensions of technological innovation (product and process innovation) on production, financial, and market performance in travel agents and hotels.

From the travel agents managers' perspective, the analysis revealed F value of (182.85, and $\mathrm{p}<.01$ ) for production performance, financial performance ( $\mathrm{F}$ value is 55.19 , and $\mathrm{p}<.01$ ), and market performance ( $\mathrm{F}$ value is 53.47 , and $\mathrm{p}<.01$ ). This proved the overall significance of the model. Table (3) shows the beta values of the technological innovation and performance dimensions in travel agents.

Table 3: Regression analysis of technological innovation and performance dimensions in travel agents

\begin{tabular}{|lcccc|}
\hline Model & B & T value & Sig. & R $^{2}$ value \\
\hline Production performance & & & & \\
\hline constant & .322 & 1.694 & .003 & .77 \\
Product innovation & .588 & 8.510 & .000 & .000 \\
Process innovation & .326 & 5.056 & & .000 \\
\hline Financial performance & & & .009 & .50 \\
\hline constant & 1.154 & 4.161 & .000 & \\
Product innovation & .268 & 2.661 & & .000 \\
Process innovation & .450 & 4.784 & .001 & .49 \\
\hline Market performance & & & .000 & \\
\hline constant & 1.066 & 3.638 & 3.436 & \\
Product innovation & .366 & 3.932 & & \\
Process innovation & .391 & &
\end{tabular}

From Table (3), it is shown the positive effect of the two dimensions of technological innovation (product and process innovations) on production performance in travel agents. It is found that production performance is significantly and positively affected by product 
innovation $(\mathrm{b}=\cdot, 588$, and $\mathrm{p}<0.01)$ ( $\mathrm{H} 1 \mathrm{a}$ is supported) and process innovation $(\mathrm{b}=0.326$, and $\mathrm{p}<0.01)$ ( $\mathrm{H} 1 \mathrm{~b}$ is supported). Those two dimensions of technological innovation explain $77 \%$ of variance in production performance in travel agents $\left(\mathrm{R}^{2}=0.77\right)$.

Findings in Table (3) show that there is a positive influence of the technological innovation on financial performance. It is obvious that financial performance is significantly and positively affected by product innovation $(b=0.268$, and $p<0.01)(\mathrm{H} 2 \mathrm{a}$ is supported) and process innovation $(\mathrm{b}=\cdot 4450$, and $\mathrm{p}<0.01)(\mathrm{H} 2 \mathrm{~b}$ is supported). The two dimensions of technological innovation explain $50 \%$ of the variance in financial performance in travel agents $\left(\mathrm{R}^{2}=0.50\right)$. In addition, there is a positive effect of the technological innovation on market performance. It is found that market performance is significantly and positively influenced by product innovation $(b=0.366$, and $p<0.01)(\mathrm{H} 3 \mathrm{a}$ is supported) and process innovation $(b=\cdot 391$, and $\mathrm{p}<0.01)$ ( $\mathrm{H} 3 \mathrm{~b}$ is supported). The dimensions of technological innovation explain $49 \%$ of the variance in market performance in travel agents $\left(\mathrm{R}^{2}=0.49\right)$.

Related to the perspective of five star hotels' managers, the analysis revealed $\mathrm{F}$ value of $(222.75$, and $\mathrm{p}<.01)$ for production performance, financial performance ( $\mathrm{F}$ value is 131.34 , and $\mathrm{p}<.01$ ), and for market performance (F value is 74.66 , and $\mathrm{p}<.01$ ). This leads to decide that the model is significant. Table (4) shows the regression analysis of the technological innovation and performance dimensions in five star hotels.

Table 4. Regression analysis of technological innovation and performance dimensions in five star hotels

\begin{tabular}{|llccc|}
\hline Model & B & T value & Sig. & R $^{2}$ value \\
\hline Production performance & & & & \\
\hline constant & .037 & .200 & .044 & .84 \\
Product innovation & .518 & 5.985 & .000 & .000 \\
Process innovation & .464 & 5.014 & & \\
\hline Financial performance & & & .017 & .76 \\
\hline constant & .525 & 2.432 & .006 & .000 \\
Product innovation & .285 & 2.843 & & \\
Process innovation & .597 & 5.573 & .033 & .64 \\
\hline Market performance & & & .009 & .000 \\
\hline constant & .592 & 2.171 & \\
Product innovation & .031 & 2243 & & \\
Process innovation & .804 & 5.938 & &
\end{tabular}

From table (4), it is appeared the positive influence of the two dimensions of technological innovation on production performance in five star hotels. It is found that production performance is significantly and positively affected by product innovation $(\mathrm{b}=$ $\cdot, 518$, and $\mathrm{p}<0.01$ ) ( $\mathrm{H} 1 \mathrm{a}$ is supported) and process innovation $(\mathrm{b}=0.464$, and $\mathrm{p}<0.01)$ ( $\mathrm{H} 1 \mathrm{~b}$ is supported). The two dimensions of technological innovation explain $84 \%$ of production performance $\left(\mathrm{R}^{2}=0.84\right)$.

Additionally, results in Table (4), show that there is a positive influence of the technological innovation on financial performance. It is found that financial performance is significantly and positively affected by product innovation $(b=0.258$, and $\mathrm{p}<0.01)(\mathrm{H} 2 \mathrm{a}$ is confirmed) and process innovation $(b=\cdot 597$, and $\mathrm{p}<0.01)$ ( $\mathrm{H} 2 \mathrm{~b}$ is supported). The 
dimensions of technological innovation explain $76 \%$ of financial performance $\left(\mathrm{R}^{2}=0.76\right)$. Moreover, there is a positive effect of the technological innovation on market performance. It is clear that market performance is significantly and positively affected by product innovation $(b=0.031$, and $\mathrm{p}<0.01)$ ( $\mathrm{H} 3 \mathrm{a}$ is confirmed) and process innovation $(\mathrm{b}=$ $\cdot, 804$, and $\mathrm{p}<0.01$ ) ( $\mathrm{H} 3 \mathrm{~b}$ is confirmed). The dimensions of technological innovation explain $64 \%$ of market performance $\left(\mathrm{R}^{2}=0.64\right)$ in five star hotels in Egypt.

\section{Discussion of Findings}

Tourism is a large industry with constant challenges, which need integration between technology and processes to adopt new products and services and to achieve competitive advantages. Technological innovation involves using technology in new ways to create a more efficient organization and improve harmony between technology initiatives and its goals and aims. Technological innovation has positive impacts on the performance of tourism and hospitality enterprises. These impacts could be production, financial, and market-related.

This study has concluded that travel agents and five star hotels in Egypt are applying activities to achieve technological innovation, which includes two types; product innovation and process innovation. Product innovation contains some practices. These findings are in line with the studies of OECD (2005), Polder et al., (2010), and Masood et al., (2013), which stated that product innovation, help enterprises introducing the new products/services, brining significant development in the existing products/services, and creating new lines of products/services.

In addition, the studies of Corsino and Gabriele (2010), Polder et al., (2010), and Davenport (2013), which claim that process innovation is the introduction of a new method of production, and a new way to make production more efficient or to be able to produce new or improved products. This includes improvements in the supporting activities such as purchasing, accounting, maintenance, customer service, after-sales services, and internal administration and operations.

The research also revealed the influence of the dimensions of technological innovation on production, financial, and market performance of travel agents and hotels in Egypt. In travel agents, process innovation has greater effect on the production performance than product innovation. Meanwhile product innovation has greater influence on the financial and market performance than process innovation. Similarly, in five star hotels, it is found that process innovation has better impact on the production performance than product innovation. It is found also that product innovation has greater influence on the financial and market performance than process innovation in five star hotels.

From these results, it is clear that technological innovation has a significant impact on production performance in Egyptian travel agents and hotels. This finding is in line with the studies of Masood, et al (2013) and Azubuike (2014), who found that product innovation and process innovation have a significant impact on production performance. This is through providing new products and services to the market comparing to competitors, introducing innovative processes and methods, high quality of new products and services introduced, increasing production volume, production flexibility, speed delivery of products, and conformance quality.

Moreover, the study revealed that technological innovation has a significant impact on financial performance of Egyptian travel agents and hotels. This results is agreed by a 
previous studies such as (Azubuike, 2014; Gopalakrishnan, 2000; Masood, et al., 2013), which mentioned that technological innovations types have positively affected the financial performance of enterprises which including production cost, increasing profits, and returning on investment. In addition, the study of Gopalakrishnan(2000) who found a positive relationship between speed of adoption of innovations and financial performance in enterprise. And the study of Cainelli et, al. (2006) mentioned that innovation has a positive impact on the economic performance of service organizations including tourism and hospitality enterprises.

Furthermore, there is a positive impact of the technological innovation on market performance of Egyptian travel agents and hotels. These results are agreed by previous studies such as (Al-Zyadaat, Saudi, \& Al-Awamreh, 2012; Azubuike, 2014; Masood, et al., 2013) who found that market performance affected by technological innovation, especially on customer satisfaction, market share, and total sales. In addition to the study of Chen \& Tsou(2007) who claimed that innovation technology influences the competitive advantage of enterprises. Additionally, the study of Naveed, et al. (2012) who mentioned that technological innovation has influenced customer loyalty.

\section{Conclusion, Implications, and Recommendations}

Recently, innovation has emerged as a pressing theme for most enterprises involved in service industry. Tourism is a growing and an extremely competitive industry. To be competitive, tourism and hotel enterprises need do innovate, responding to the more and more demanding of tourists. Nonetheless, research on this field is limited and insufficient. In order to shed light on this important phenomenon, a comparative study was conducted to investigate the impact of technological innovation on performance of Egyptian travel agents and hotels.

The results show that travel agents and hotels in Egypt are applying technological innovation, which includes product innovation and process innovation. The research also revealed the influence of product innovation on production, financial, and market performance of travel agents and hotels in Egypt. Furthermore, there is a positive impact of process innovation on production, financial, and market performance of travel agents and hotels in Egypt.

This study contributes to extant knowledge by introducing the influence of technological innovation on performance of travel agents and hotels. The current study responds to the claim that there is a limited research in innovation area and tourism. Another implication is providing evidence from tourism industry in Egypt as a developing country that could be compared later with a developed country. This study contributes also to practice. It clearly indicates the positive impacts of technological innovation on performance of travel agents and hotels. A clear equation of technological innovation and its influence on performance is introduced to travel agents and hotels. This equation implies the higher the level of innovation in travel agents and hotels, the higher the level of performance they achieve.

To form the road map of innovation implementation and to take the full advantages of it, Egyptian travel agencies and hotels have to recognize the importance of innovation on performance. They should invest more on innovative capabilities and support new attempts of introducing innovation on each type. Moreover, they should work on the 
existence of solutions and overcome the obstacles to the adoption of innovation. They may focus on organizational structure, human resources, leadership, and IT infrastructure.

\section{Limitation and Future Research}

Similar to any other study, this study has some limitations. Along with the important findings obtained in this study, it could be argued that this approach has given biased results. Perhaps this is due to the reason that the study based on the viewpoint of managers only in the travel agencies and hotels. This study was conducted only on travel agents category ' $A$ ' and five star hotels in Egypt. Finally, for the quantitative data collection, there was a general desire among the respondents not to provide any personal information about themselves or their enterprises, despite the assurances of the researcher that the data would remain confidential. The researcher had to agree to this request and it resulted in a lack of descriptive statistics on study respondents.

Building upon the discussed limitations, future research should address these limitations and could compare the findings of this study with another study would be conducted in a developed country. Future venues of research should focus on other types of innovation within travel agents and hotels to achieve better performance of these enterprises.

\section{References}

- Adeyeye, A. D., Jegede, O. O., \& Akinwale, Y. O. (2013). The impact of technology innovation and R\&D on firms' performance: an empirical analysis of Nigeria's service sector. International Journal of Technological Learning, Innovation and Development, 6(4), 374-395.

- Adner, R., \& Levinthal, D. (2001). Demand heterogeneity and technology evolution: implications for product and process innovation. Management science, 47(5), 611-628.

- Agbim, K. C. (2013). The relative contribution of management skills to entrepreneurial success: A survey of small and medium enterprises (SMEs) in the trade sector. International Organization of Scientific Research Journal of Business and Management, 7(1), 08-16.

- Al-Zyadaat, M. A., Saudi, M. A., \& Al-Awamreh, M. A. (2012). The Relationship Between Innovation and Marketing Performance in Business Organizations: An Empirical Study on Industrial Organizations in the Industrial City of King Abdullah II. International Business and Management, 5(2), 76-84.

- Archibugi, D., \& Coco, A. (2005). Measuring technological capabilities at the country level: A survey and a menu for choice. Research Policy, 34(2), 175-194.

- Ashari, H. A., Heidari, M., \& Parvaresh, S. (2014). Improving SMTEs' Business Performance through Strategic Use of Information Communication Technology: ICT and Tourism Challenges and Opportunities. International Journal of Academic Research in Accounting, Finance and Management Sciences, 4(3), 1-20.

- Azubuike, V. M. (2014). Technological Innovation Capability and Firm's Performance in New Product Development. Communications of the IIMA, 13(1), 4.

- Benner, M. J., \& Tushman, M. (2002). Process management and technological innovation: A longitudinal study of the photography and paint industries. Administrative Science Quarterly, 47(4), 676-707.

- Berry, L. L., Shankar, V., Parish, J. T., Cadwallader, S., \& Dotzel, T. (2006). Creating new markets through service innovation. MIT Sloan Management Review, 47(2), 56.

- Cabral, J. d. O. (2011). Firms' dynamic capabilities, innovative types and sustainability: a theoretical framework. Paper presented at the Embrapa Agroindústria Tropical-Artigo em anais de congresso (ALICE).

- Cainelli, G., Evangelista, R., \& Savona, M. (2006). Innovation and economic performance in services: a firmlevel analysis. Cambridge Journal of Economics, 30(3), 435-458.

- Carson, D., \& Richards, F. (2004). Delivering technological innovation in tourism: Considerations in the implementation of decipher: na.

- Castellacci, F. (2008). Technological paradigms, regimes and trajectories: Manufacturing and service industries in a new taxonomy of sectoral patterns of innovation. Research Policy, 37(6), 978-994. 
- Chen, J., \& Tsou, H.-T. (2007). Information technology adoption for service innovation practices and competitive advantage: the case of financial firms. Information Research, 12(3), 7.

- Cooper, L. P. (2003). A research agenda to reduce risk in new product development through knowledge management: a practitioner perspective. Journal of Engineering and Technology Management, 20(1), 117-140.

- Corsino, M., \& Gabriele, R. (2010). Product innovation and firm growth: evidence from the integrated circuit industry. Industrial and Corporate Change, dtq050.

- Corso, M., \& Paolucci, E. (2001). Fostering innovation and knowledge transfer in product development through information technology. International Journal of Technology Management, 22(1-3), 126-148.

- Davenport, T. H. (2013). Process innovation: reengineering work through information technology. London: Harvard Business Press.

- Dewett, T., \& Jones, G. R. (2001). The role of information technology in the organization: a review, model, and assessment. Journal of management, 27(3), 313-346.

- Drucker, P. F. (2002). The discipline of innovation. 1985. Harvard business review, 80(8), 95-100, 102, 148.

- Egyptian Travel Agents Association. (2013). Agencies Directory. Cairo, Egypt: ETTA: Ministry of Tourism.

- Egyptian Travel Agents Association. (2014). Agencies Directory. Cairo, Egypt: Ministry of Tourism.

- Fortuin, F., Batterink, M., \& Omta, S. (2007). Key success factors of innovation in multinational agrifood prospector companies. International Food \& Agribusiness Management Review, 10(4), 1-24.

- Gad-ElRab, M. S. (2010). Computer Applications to the Hospitality Purchasing in Greater Cairo Hotels. A thesis submitted in Partial Fulfillment of the Requirements for the PhD Degree in Hotel Management, Fayoum University, Egypt.

- Gopalakrishnan, S. (2000). Unraveling the links between dimensions of innovation and organizational performance. The Journal of High Technology Management Research, 11(1), 137-153.

- Gunday, G., Ulusoy, G., Kilic, K., \& Alpkan, L. (2011). Effects of innovation types on firm performance. International Journal of Production Economics, 133(2), 662-676.

- Hair, J. F., Black, W. C., Babin, B. J., Anderson, R. E., \& Tatham, R. L. (2006). Multivariate data analysis (Vol. 6): Pearson Prentice Hall Upper Saddle River, NJ.

- Haiyu, H., \& Qian, P. (2014). A research on information technology applied to improving performance for tourism enterprises. Journal of Chemical and Pharmaceutical Research, 6(6), 1418-1424.

- Hamidi, S., \& Benabdeljlil, N. (2015). Managerial and Technological Innovations: Any Relationship? Procedia-Social and Behavioral Sciences, 181, 286-292.

- Hassan, S., \& Soliman, M. (2013). Travel Agencies Management: Faculty of Tourism and Hotels. Fayoum University, Egypt.

- Ivanovic, S., Katic, A., \& Mikinac, K. (2010). Cluster as a model of sustainable competitiveness of small and medium entrepreneurship in the tourist market. UTMS Journal of economics, 1(2), 45-54.

- Lam, A. (2004). Organizational innovation. London: Brunel University, Brunel Research in Enterprise, Uxbridge,.

- Letangule, S. L., \& Letting, N. K. (2012). Technological Innovation and Corporate Performance. IJMBS, 2(3), 66-72.

- Lin, C.-Y., \& Ho, Y.-H. (2008). Technological innovation for China's logistics industry. Journal of Technology Management \& Innovation, 2(4), 1-19.

- Macerinskiene, A., \& Mikaliuniene, G. (2014). Peculiarities of Tourism Business Innovations in lithuania. European Journal of Tourism, Hospitality and Recreation(Special Issue), pp. 231-255.

- Masood, H. U., Shaukat, S., Nawaz, M. S., \& Naz, S. (2013). Effects of Innovation Types on Firm Performance: An Empirical Study on Pakistan's Manufacturing Sector. Pakistan Journal of Commerce \& Social Sciences, 7(2).

- Meneses, O. A., \& Teixeira, A. A. (2011). The innovative behaviour of tourism firms. Economics and Management Research Projects: An International Journal, 1(1), 25-35.

- Minazzi, R. (2010). Hotel classification systems: a comparison of international case studies. Acta Universitatis Danubius. Economica, 6(4).

- Möller, K., Rajala, R., \& Westerlund, M. (2008). Service innovation myopia? A new recipe for client-provider value creation. California Management Review, 50(3), 31-48.

- Moscardo, G. (2008). Sustainable tourism innovation: Challenging basic assumptions. Tourism and Hospitality Research, 8(1), 4-13.

- Narangajavana, Y. (2007). The Relationship of the Hotel Rating System and Service Quality. in partial fulfillment of the requirements for the degree of Doctoral of Philosophy, Oklahoma State University. 
- Naveed, T., Akhtar, I., \& Cheema, K. U. R. (2012). The impact of innovation on customer satisfaction and brand loyalty: A study of the students of Faisalabad. International Journal of Management \& Organizational Studies, 2(2), 62-68.

- Netemeyer, R. G., Bearden, W. O., \& Sharma, S. (2003). Scaling procedures: Issues and applications. London: Sage.

- OECD. (2005). Oslo manual: Guidelines for collecting and interpreting innovation data. Paris: Publications de l'OECD.

- Orfila-Sintes, F., \& Mattsson, J. (2009). Innovation behavior in the hotel industry. Omega, 37(2), 380-394.

- Perez, A. (2012). New technologies and their relationship with quality and human resources in the Spanish hotel industry: University of Valencia. Spain.

- Peters, M., \& Pikkemaat, B. (2006). Innovation in Tourism. Journal of Quality Assurance in Hospitality \& Tourism, 6, 3-4.

- Pirnar, I., Bulut, C., \& Eris, E. D. (2012). Improving the performance and competitiveness of tourism establishments by means of innovation: trends and applications. national research council, Institute for services industry research, 133-142.

- Polder, M., Leeuwen, G. v., Mohnen, P., \& Raymond, W. (2010). Product, process and organizational innovation: drivers, complementarity and productivity effects. CIRANO-Scientific Publications 2010 s-28.

- Rampersad, G., Plewa, C., \& Troshani, I. (2012). Investigating the use of information technology in managing innovation: A case study from a university technology transfer office. Journal of Engineering and Technology Management, 29(1), 3-21.

- Roberts, P. W. (1999). Product innovation, product-market competition and persistent profitability in the US pharmaceutical industry. Strategic management journal, 20(7), 655-670.

- Rouse, M. (2011). IT innovation definition Retrieved 1-9, 2015, from http://searchcio.techtarget.com/definition/IT-innovation

- Schmidt, T., \& Rammer, C. (2007). Non-technological and technological innovation: strange bedfellows? ZEWCentre for European Economic Research Discussion Paper(07-052).

- Sekaran, U. (2006). Research methods for business: A skill building approach. Sussex, UK: John Wiley \& Sons.

- Sipe, L. J., \& Testa, M. (2009). What is innovation in the hospitality and tourism marketplace? A suggested research framework and outputs typology. Paper presented at the International CHRIE Conference-Refereed Track.

- Streiner, D. L. (2003). Starting at the beginning: an introduction to coefficient alpha and internal consistency. Journal of personality assessment, 80(1), 99-103.

- Susman, G., Warren, A., Ding, M., \& Stites, J. P. (2006). Product and service innovation in small and mediumsized enterprises. Research Sponsored by United States Department of Commerce-The National Institute of Standards and Technology Manufacturing Extension Partnership.

- Teece, D. J. (2007). Explicating dynamic capabilities: the nature and microfoundations of (sustainable) enterprise performance. Strategic management journal, 28(13), 1319-1350.

- Tsai, Y., Lin, J. Y., \& Kurekova, L. (2009). Innovative R\&D and optimal investment under uncertainty in hightech industries: An implication for emerging economies. Research Policy, 38(8), 1388-1395.

- Vogt, W. P. (2007). Quantitative research methods for professionals. London: Pearson Education, Inc.

- Weiermair, K. (2006). Product improvement or innovation: What is the key to success in tourism. In OECD (Ed.), Innovation and Growth in Tourism (pp. 53-67). Paris.

- Xu, H., Sharma, S. K., \& Hackney, R. (2005). Web services innovation research: Towards a dual-core model. International Journal of Information Management, 25(4), 321-334.

- Yam, R. C., Guan, J. C., Pun, K. F., \& Tang, E. P. (2004). An audit of technological innovation capabilities in Chinese firms: some empirical findings in Beijing, China. Research Policy, 33(8), 1123-1140. 